\title{
Surface ozone impacts on major crop production in China from 2010 to 2017
}

\author{
Dianyi $\mathrm{Li}^{1}$, Drew Shindell ${ }^{1,2}$, Dian Ding ${ }^{3}$, Xiao $\mathrm{Lu}^{4,5}$, Lin Zhang ${ }^{4}$, Yuqiang Zhang ${ }^{1 *}$
}

${ }^{1}$ Nicholas School of the Environment, Duke University, 9 Circuit Dr, Durham, NC 27708

$5 \quad{ }^{2}$ Porter School of the Environment and Earth Sciences, Tel Aviv University, Tel Aviv, Israel

${ }^{3}$ State Key Joint Laboratory of Environmental Simulation and Pollution Control, School of Environment, Tsinghua University, Beijing, China

${ }^{4}$ Laboratory for Climate and Ocean-Atmosphere Studies, Department of Atmospheric and Oceanic Sciences, School of Physics, Peking University, Beijing 100871, China

$10{ }^{5}$ John A. Paulson School of Engineering and Applied Sciences, Harvard University, Cambridge, Massachusetts 02138, United States

Correspondence to: Yuqiang Zhang (Yuqiang.Zhang@duke.edu; YuqiangZhang.thu@gmail.com)

\begin{abstract}
Exposure to elevated surface ozone is damaging to crops. In this study, we performed an analysis of temporal and spatial distributions of relative yield losses (RYLs) attributable to surface ozone for major crops in China from 2010 to 2017 ,

15 by applying the AOT40 metrics (hourly ozone concentration over a threshold of $40 \mathrm{ppbv}$ during the growing season) simulated by chemical transport model. The major crops in China include wheat, rice (including double early \& late rice, and single rice), maize (including north and south maize) and soybean. The aggregated production and associated economic losses in China and major provinces were evaluated by combing annual crop production yields with crop purchase prices. We estimated that, from our model simulations, the national annual average AOT40 in China increased from $21.98 \mathrm{ppm} \mathrm{h}$ in 2010 to $23.85 \mathrm{ppm}$
\end{abstract}

20 h 2017, with a peak value of $35.69 \mathrm{ppm} \mathrm{h}$ in 2014. There exists significant spatial heterogeneity for the AOT40 and RYLs across the four crops due to the different growing seasons for each crop. We estimated that national mean RYLs were 11.45\%$19.74 \%$ for wheat, $7.59 \%-9.29 \%$ for rice, $0.07 \%-3.35 \%$ for maize, and $0.87 \%-2.74 \%$ for soybean during 2010 to 2017 . The associated ozone-induced annual average crop yield losses were estimated 13.81-36.51 million metric tons (Mt) for wheat, 16.89-20.03 million Mt for rice, 4.59-8.17 million Mt for maize, and 0.27-0.34 million Mt for soybean, which accounted for annual average economic loss of $\$ 9.55$ billion, $\$ 8.53$ billion, $\$ 2.23$ billion, and $\$ 0.22$ billion individually over the 8 years. Our results provide first, long-term quantitative estimation of crops yield losses and their economic cost from surface ozone exposure in China before and after the China Clean Air Act, and improve the understanding of the spatial sensitivity of Chinese crops to ozone impacts. 


\section{Introduction}

Tropospheric ozone, as a secondary air pollutant, is harmful to both human and vegetation health (Booker et al., 2009; Van Dingenen et al., 2009; Brauer et al., 2013). Since the $19^{\text {th }}$ century, rapid industrialization and urbanization have significantly elevated the background ozone concentration in the Northern Hemisphere (The Royal Society, 2008). As a greenhouse gas that is not directly emitted by human activities, tropospheric ozone is mainly generated from sunlight driven photochemical oxidation of volatile organic compounds (VOC), carbon monoxide or methane in the presence of $\mathrm{NO}_{\mathrm{X}}$ (Atkinson, 2000). In the past few decades, the strong linkage between fossil fuel usage and economic growth boosted emissions of ozone precursors in China. Since 2012, due to the severe fine particulate matter $\left(\mathrm{PM}_{2.5}\right)$ pollution in China, the Chinese government has adopted a stringent emission and pollution monitoring and control policy (the so-called Air Pollution Prevention and Control Action Plan (APPCAP), Zhang et al., 2016). The APPCAP has led to a significant decline of air pollutants emissions, including 17\%

40 decreases of anthropogenic emission of $\mathrm{NO}_{x}, 27 \%$ of $\mathrm{CO}$, and $62 \%$ of $\mathrm{SO}_{2}$ from 2010 to 2017 (Zheng et al., 2018). These significant emissions reductions have led to $-33 \%$ decline of annual $\mathrm{PM}_{2.5}$ in China from 2013 to 2017, and avoided 0.41 million premature deaths (Zhang et al., 2019). At the same time, however, anthropogenic emission of VOC increased by $11 \%$ due to the lack of effective emission controls (Zheng et al., 2018) and surface observations show that the ozone concentration in China still reveals a tendency of increasing (Wang et al., 2019; Li et al., 2018 \& 2019; Lu et al., 2018, 2020).

45 The growth of ozone concentrations in China has led to emerging concerns (Lu et al., 2018, 2020). As indicated in many biological and ecological studies, high ozone concentration can seriously damage vegetation and substantially impair crop yield, which leads to economic costs and threatens food security (Krupa et al., 1998; Mills et al., 2007; Van Dingenen et al., 2009, 2018; Avnery et al., 2011a, b). Based on different field-based concertation-response studies, for the year 2000 surface ozone exposure induced crop yield reductions of 3.9\%-15\% for wheat, $2.2 \%-5.5 \%$ for maize, and $8.5 \%-14.0 \%$ for soybeans,

50 with global crop production loss of 79-121 million Mt (Avnery et al., 2011a; Tang et al., 2013). For Eastern Asia, the ozoneinduced maize reduction loss is around 3.8\%, 17\% for wheat, and as high as 21\% for soybean in 2000 (Avnery et al., 2011a; Tang et al., 2013). Throughout China specifically, by 2020 exposure to surface ozone was projected to decrease maize production by $7.2 \%$, wheat (including both winter and spring wheat) by $13.4 \%-29.3 \%$, and soybean by $18 \%-21 \%$ (Aunan et al., 2000; Tang et at., 2013; Feng et al., 2015). A recent study by Lin et al. (2018) estimated that exposure to surface ozone in

552014 could cause 78.4 million metric tons (Mt) of production losses from all crops, including winter wheat, rice and maize. By using observational data, the exposure to surface ozone in the North China Plain (NCP) was estimated to cause annual average of 2.3 billion USD loss for maize and 9.3 billion USD for wheat from 2014 to 2017 (Feng et al., 2020; Hu et al., 2020). To date, very few studies have investigated the long-term trends and spatial patterns of ozone impacts on crop production in China. Previous studies mainly focused on the crop production loss from ozone at the global scale, or on short time periods

60 and/or regional spatial coverage (Rosenzweig et al. 2014; Zhao et al. 2017; Lin et al., 2018; Hu et al., 2020; Feng et al., 2019, 2020; Zhao et al., 2020). In this study, we focus on the long-term ozone-exposure impact analysis from 2010 to 2017 in China to assess the yield losses of four major crops (wheat, maize, rice, and soybean) and evaluate their associated economic losses. 
The study aims to present a comprehensive analysis of ozone-induce crop yield losses and economic impacts in the agriculture sector before and after the China APPCAP. Such an analysis is expected to provide scientific support to policymakers for their decision making.

\section{Methodology}

\subsection{Model simulated hourly ozone and surface observation in China}

Hourly ozone concentration over China from 2010 to 2017 were simulated by using a state-of-the-art global chemistry model (CAM_Chem, Lamarque et al., 2012). The original model was run at a horizontal resolution of $1.9^{\circ} \times 2.5^{\circ}$ (Zhang et al, 2016;

70 2020), and then regridded to $1^{\circ} \times 1^{\circ}$ to match the crop production data (see section 2.2). The anthropogenic emissions in China from 2010 to 2017 are from the Multi-resolution Emission Inventory (MEIC) developed by Tsinghua University (http://meicmodel.org/, last access July 15, 2020). Emissions outside China are from the Community Emissions Data System (CEDS) which were prepared for the Coupled Model Intercomparison Project Phase 6 (CMIP6) experiments (Hoesly et al., 2018). Hourly surface ozone was saved from 2010 to 2017 from the model simulation. We then adjusted the model simulated

75 surface ozone from its higher altitude (usually above 30 meters) to a lower altitude (usually 3-5 meters at the ambient observation sites), following previous methods (Van Dingenen et al., 2009; Zhang et al., 2012).

We first evaluated the model's performance by comparing the model simulated AOT40 with the surface observation during the growth season (April to September) from 2013 to 2017, which were downloaded from National Environmental Monitoring Center (CNEMC) Network (http://106.37.208.233:20035/). It collects at least 100 million environmental monitoring data from

801497 established air quality monitoring stations annually for national environmental quality assessment. The ozone observation data before 2013 were not available (Lu et al., 2018, 2020). In general, the model simulated AOT40 values were lower than the observation data, with normalized mean bias ranging from -5\% in 2015 to $-28 \%$ in 2017 (Table S1). This indicates that our estimation on crop production loss and associated economic loss are conservative estimations.

\subsection{Ozone crop metrics}

85 In order to assess the crop yield loss from exposure to surface ozone, many different crop-ozone matrixes are developed to measure the chronic ozone exposure risk of vegetation (e.g., Wang and Mauzerall, 2004; Van Dingenen et al., 2009; Avnery et al., 2011a, b;). In this study, we adopted the ozone metric of AOT40 which is among the commonly used metrics in crop yield assessment. AOT40 is calculated by summing up hourly ozone exposure concentration over the threshold of 40 ppbv during the $12 \mathrm{~h}$ (08:00-19:59 China Standard Time) (equation 1). By counting concentration over 40ppbv, AOT40 is

90 able to sensitively capture the influence of extremely high ozone concentration (Van Dingenen et al., 2009; Hollaway et al., 2012). In a synthesis study by Mills et al. (2007), the AOT40 showed a statistically significant relationship with many crops. 
AOT $40=\sum_{i=1}^{n}\left(\left[O_{3}\right]_{i}-0.04\right)$, for $\left[O_{3}\right]_{i} \geq 0.04 \mathrm{ppm}$

In the equation (1), $\left[\mathrm{O}_{3}\right]_{i}$ denotes the hourly ozone concentration level during daylight hours (8:00am - 7:59pm, GMT+8) at each grid cell $(i), n$ is the total hours of growing season which was counted as the 3-month harvest season based on the crop calendar (Lin et al., 2018), or 75 days composed by 44 days and 31 days before and after the anthesis dates (Feng et al., 2019, 2020). Growing seasons for wheat, rice, maize and soybeans were acquired from Major World Crop Areas and Climate Profiles (MWCACP), and the Food and Agriculture Organization of the United Nation (FAO) (Lin et al., 2018; Zhao et al., 2020). In this study, we focused on four major crops — wheat, rice (including double early rice and late rice, and single rice), maize (including north maize and south maize), and soybean.

\subsection{Crop relative yields and economic losses}

In our study, relative yield (RY) was calculated based on the exposure-response function (ERF) provided by Mills et al. (2007), where RY is in \% and AOT 40 is in ppm h (Table 1). The ERF for north maize and south maize is the same with different growing seasons and growing areas (Table 1; NBSC, 2018; Zhou et al., 2019; Zhao et al., 2020). The same ERF applies to all the rice, with differences in growing season and provinces as well (Table 1).

105 The relative yield loss $\left(R Y L_{i}\right)$ in each grid cell was then calculated in equation (2).

$R Y L_{i}=1-R Y_{i}$

The crop production loss $\left(C P L_{i}\right)$ was then calculated using equation 3 (Wang and Mauzerall, 2004; Dingenen et al., 2009; Avnery et al., 2011a,b):

$C P L_{i}=C P_{i} \times \frac{R Y L_{i}}{1-R Y L_{i}}$

110 where $C P_{i}$ is the annual crop production with unit of $1000 \mathrm{Mt}$ per year. Grid cell annual crop production data for major crops was originally developed by Van Dingenen et al. (2009) from USDA national and regional production numbers and AgroEcological Zones suitability index. It contains global crop production data in 2000 with horizontal resolution of $1^{\circ} \times 1^{\circ}$. We then scaled the annual national total crop yields in China to match the yearly data from the Statistical Yearbook of China from 2010 to 2017 (http://www.stats.gov.cn/tjsj/ndsj/2019/indexeh.htm, last accessed 26th, March, 2020). For provinces growing

115 both double and single Rice (such as Zhejiang and Jiangxi, see the highlighted bold notes in Table 1), the fractions for double and single rice production were scaled based on the production data from the National Bureau of Statistics (http://data.stats.gov.cn, last accessed 26th, March, 2020). For provinces growing double early/late rice only, the rice productions were assumed to be equal for each rice.

National average relative yields loss ( $A R Y L$, unit of \%), is then calculated based on $C P L_{i}$ and $C P_{i}$ to identify the fractions of production loss in total crop production (Equation 4):

$A R Y L_{i}=\frac{C P L_{i}}{C P_{i}+C P L_{i}} \times 100 \%$ 
National economics costs for each crops $\left(E C_{p}\right)$ were then quantified by multiplying the purchase price in each year using equation 5:

$E C_{p}=C P L_{p} \times$ Crop Price $_{p}$

125 where Crop Price $_{p}$ stands for the purchase price for each crop in every year with unit of \$/Mt. Crops purchase prices were acquired from the FAOSTAT (http://www.fao.org/faostat/, last accessed 26th, March, 2020). The purchase price from the FAOSTAT is not available for the major crops in 2017 except for maize, so we used the 3-year average from 2014 to 2016 to calculate economic losses in 2017 for wheat, rice, and soybean. From 2010 to 2017, soybean has the highest crop purchase price, ranging from $677.9 \$$ ton to $869.7 \$ /$ ton, followed by rice (296.6 \$/ton to $559.9 \$ /$ ton), wheat (279.5 \$/ton - $391.4 \$ /$ ton) and maize (252.2 \$/ton - 489.1 \$/ton). For soybean, wheat and maize, the purchase price usually peaks in 2014 or 2015 , which contributed to the peak economics loss in these years (see section 3.3).

\section{Results}

\subsection{Temporal and spatial distribution of ozone concentration change}

Since the four crops have distinct growing seasons (Table 1), thus different accumulated AOT40 values, here we present the annual accumulated AOT40 in China from 2010 to 2017. From Fig. 1 we see that the 8-yr average annual accumulated AOT40 values are usually larger than $16 \mathrm{ppm}$ h, with hotspots identified in western China (40-56 ppm h), Beijing-Tianjin-Hebei (a.k.a. JJJ, 32-40 ppm h), northeastern China (24-32 ppm h) as well as Yangtze Delta Region (YRD, Fig. S1). At provinces level, Xizang (41.47 ppm h for 8-year average), Tianjin (34.79 ppm h) and Qinghai (34.51 ppm h) are the top three provinces with the highest annual accumulated AOT40 (Table S2). For the temporal changes, we conclude that the national annual

140 accumulated AOT40 has been increasing from $21.98 \mathrm{ppm} \mathrm{h}$ in 2010 to $23.85 \mathrm{ppm} \mathrm{h}$ in 2017, with peak of $35.69 \mathrm{ppm} \mathrm{h}$ in 2014 (Fig. 2). The increases trend of ozone in China even though the precursors were decreasing after 2010 (Li et al., 2017; Zheng et al., 2018), were also reported in previous studies utilizing both surface observations and modelling data (Lu et al., 2018, 2020; Li et al., 2020; Liu and Wang, 2020a), and were caused by a combination of unfavourable meteorological conditions, the unmitigated missions of volatile organic compounds and the decrease of $\mathrm{PM}_{2.5}$ (Li et al., 2018, 2019, 2020; Liu and Wang,

145 2020b). The peak value of the annual accumulated AOT40 in 2014 as well adjacent years were mainly caused by the high ozone values in the western China (Fig. S1), mainly dominated by the transboundary transport from foreign sources driven by strong westerly winds and stratosphere-troposphere exchange (Zhang et al., 2008; Wang et al., 2011; Ni et al., 2018; Lu et al., 2019).

\subsection{Growing-season ozone concentration and relative yield loss (RYL)}

150 During the growing season for the wheat (March, April and May), the accumulated AOT40 concentration revealed to be higher in the Tibet Plateau and YRD, and lower in the south China, such as Hainan, Guangdong and Guangxi (Fig. 3a; Table S3). At 
province level (Table S3), the highest AOT40 is in Xizang (14.99 ppm h), following by Yunan (12.60 ppm h) and Qinghai (11.77 ppm h), with the lowest values in Hainan (4.43 ppm h). We also notice that the AOT40 values for wheat were decreasing in the western China, but increasing in the middle and eastern China from 2010 to 2017 (Fig. S2), which were caused by a combination of unfavourable meteorological conditions and decreased anthropogenic emissions (Liu and Wang, 2020a). The RYL for wheat have the similar spatial patterns as AOT40, with highest of 25.14\% in Xizang for the 8-yr average, and lowest of $8.13 \%$ in Hainan (Table S3).

The AOT40 values for double early rice (May, June, July) are lower than those for wheat (Fig. 3b), with highest province in Anhui (12.09 ppm h), and lowest in Hainan (1.84 ppm h; Table S4). The AOT40 values for double late rice are much lower than the early rice (Fig.3c), with highest in Fujian (6.47 ppm h), and lowest in Yunan (2.86 ppm h; Table S4). The spatial distribution of AOT40 for the early and late rice varies as well, with the hotspots in eastern China for early rice and southern China for late rice (Figs. S3-S4). The RYLs ranges from 10.71\% in Anhui to 7.11\% in Yunan for the 8-yr average (Table S4). For the single rice, the NCP experiences high ozone exposure during the growing season (AUG, SEP, OCT), and lower in southern China (Fig. 3d). AOT40 level ranges from $1.0 \mathrm{ppm} \mathrm{h}$ (Yunnan in 2017) to $14.1 \mathrm{ppm} \mathrm{h}$ (Tianjin in 2015). Highest RYLs for the single rice are identified in the North China Plain including Tianjin (8-year average RYL of 10.22\%), Shanxi (9.81\%), and Henan (9.67\%; Table S5).

Hotspots for the AOT40 values for the north maize during growing season (JUNE, JULY, AUG) are identified in the NCP (Fig. 3e; Fig. S7), including Tianjin (20.24ppm h), Beijing (17.92 ppm h), and Hebei (17.80 ppm h). The provincial averaged RYLs range from $0.48 \%$ in Qinghai to $5.29 \%$ in Tianjin (Table S6). When looking at the AOT40 values for the south maize

(AUG, SEP, OCT), we found that they are much lower than the north maize, with the highest in Jiangsu ( $8.18 \mathrm{ppm} \mathrm{h}$ for 8 -yr average) and lowest in Yunan (2.02 ppm h). For the spatial pattern, the AOT40 values are higher in the western China, but lower in the south China (Fig. 3d; Fig. S7). The 8-year averaged RYLs for each province is all below 1\% (Table S6).

The growing seasons for soybean are the same as north maize, and thus they have the same hotpots as in NCP (Fig. 3e). For the 8-yr average, the highest AOT40 values is in Tianjin (20.2 ppm h with RYL of 11.48\%), followed by Beijing (17.9 ppm h with RYL of $8.79 \%$ ), and Hebei (17.8 ppm h with RYL 8.65\%) (Table S7).

\subsection{Crop production loss (CPL)}

From the Statistical Yearbook of China, the national wheat production increased from 115.19 million Mt in 2010 to 134.34 million Mt in 2017, which are mainly planted in the NCP. From equation 3, we estimated that on average, 26.42 million Mt of wheat will be lost in China due to surface ozone exposure, ranging from 13.81 million Mt in 2010 to 36.51 million Mt in 2015

180 (Fig. 4; Table S8). The annual national wheat CPLs in China are comparable to the total wheat production in France (29.5 to 42.8 million Mt from 2010 to 2017), which is the fifth largest wheat production in the world (http://www.fao.org/faostat/en/\#data/QC, accessed November 30, 2020). Fig. 5 shows the CPL for each province in China from 2010 to 2017, with the top 5 provinces including Henan (5.23 million Mt for 8-yr average), Shandong (4.77), Hebei 
(2.79), Jiangsu (2.66), and Anhui (2.58). We conclude that the wheat CPL due to ozone exposure were increasing from 2010

to 2017, with the peak year varying from province to province, but generally late than 2014 (Table S8). The hotspots for the wheat product losses were in the NCP, inconsistent with the patterns of RYL (Fig. S2), which is not surprising since the regions with high RYL, such as western China, usually have very limited wheat productions.

National double rice (including both early and late rice) production ranges from 77.94 million Mt to 80.70 million Mt from 2010 to 2017. We estimated that the national CPL for the early rice is between 3.51 million Mt and 3.92 million Mt in China with 8-yr average of 3.60 million Mt (Fig. 3; Table S9). The CPL for the late rice is comparable with the early rice, ranging from 3.21 to 3.93 with 8-yr average of 3.61 million Mt (Fig. 3; Table S10). The CPL for double early and late rice both peak in 2014, but with different years for lowest values (Tables S9 and S10), highlighting the differences in the calculations of the growing season (Table 1). In China, there are more provinces (27) growing single rice than the double rice. The CPLs for the single rice are also higher than the double rice, ranging from 10.00 to 12.42 million $\mathrm{Mt}$, with 8-yr average of $11.37 \mathrm{million} \mathrm{Mt}$ (Fig. 3; Table S11). The leading provinces with the highest CPL for the single rice are Anhui (1.69-2.14 million Mt from 2010 to 2017), Jiangsu (1.55—1.91 million Mt), Hubei (1.13 - 1.52 million Mt), and Sichuan (1.13—1.52 million Mt), which are all exceeding 1 million Mt for the 8-yr average (Fig. 5; Table S11). CPLs for most provinces were shown to peak in 2015 (Fig. 6). The annual CPLs for all the rice range from 16.89 million Mt in 2010 to 20.03 million Mt in 2014, with 8-yr average of 18.58 million Mt, comparable to the annual rice productions in Philippines, which is the $8^{\text {th }}$ largest rice produce in the world (from 15.77 to 19.28 million Mt from 2010 to 2017, http://www.fao.org/faostat/en/\#data/QC, accessed November 30, 2020). Maize in China were mainly planted in NCP and northeastern China with north maize production dominates the total maize production (82\%). The annual maze production ranging from 177.54 million Mt in 2010 to 265.16 million Mt in 2015. We estimated that 8-yr annual average CPL for maize were 6.12 million Mt, with the peak value of 8.17 million Mt in year 2015, and lowest value of 4.59 million Mt in 2017 (Fig. 3), with largest contributions from Hebei (1.02-1.81 million Mt), Shandong (0.81-1.31 million Mt), and Henan (0.53-0.85 million Mt) (Table S12; Fig. S9). The annual national maize CPLs in China are comparable to the annual yields in Hungary, which ranks as $18^{\text {th }}$ maize production in the world.

Soybean mainly grows in the NCP as well. The total soybean production in China decreased from 15.08 million Mt in 2010 to 11.79 million Mt 2015, and then increased slightly to 13.13 million Mt in 2017. Heilongiiang is the largest soybean producer which contributes around $50 \%$ of the national soybean production (8-year average of 6.38 million Mt), followed by Anhui (1.25 million Mt) and Henan (1.03 million Mt). We estimated that the ozone-induced CPL for soybean ranges from 74 thousand Mt in 2017 to 338 thousands Mt in 2010, with 8-yr annual average of 263 thousands Mt (Fig. 4; Table S13). The lowest CPL in 2017 was caused by the lower AOT40 values in the northeastern China (Figs. S1 and S8). Heilongiiang, Hebei, and Henan are the three provinces with the highest CPL, with 77, 51, 41 thousand tons loss on average individually (Table S13). 


\subsection{National average relative yield loss (ARYL) and economic loss (EC)}

215 From Fig. 7, we conclude that wheat has the largest national ARYL, ranging from $11 \%$ to $22 \%$ from 2010 to 2017, comparable with previous estimates: $14 \%$ in 2015 estimated by Lin et al. (2018) using regional model simulation, and 20.1-33.3\% from 2015 to 2018 estimated by Zhao et al. (2020) using nationwide ozone monitoring data. National ARYLs for rice are around $8 \%-9 \%$, ranking in the second place among the four crops. Lowest ARYLs are observed for south maize (0-1\%). It is noteworthy that, for most crops, the highest national ARYLs were observed in 2014 while the lowest values were observed in 2010 for wheat and 2017 for other three crops (Fig. 7).

When converted to EC, we estimated that 3.86 billion to 14.29 billion\$ would be lost nationally due to surface ozone exposure on wheat (Fig. 8a), with the top five provinces all above 1 billion \$, including Henan, Shandong, Hebei, Jiangsu and Anhui (Table S8). Our estimates are consistent with previous studies, which reported 10.3 billion and 10.7 billion $\$$ for wheat in 2015 and 2016 (Feng et al., 2019). National economic loss for double early and late rice increase consistently from 2.05 billion $\$$ to 3.87 billion \$ (Fig. 8a). The top three provinces with highest losses are Hunan, Jiangxi, and Guangzhou, with 8-yr average of 0.80 billion, 0.79 billion and 0.47 billion losses individually. For the single rice, national economic loss ranges from 2.96 billion to 6.49 billion \$ (Fig. 8a), with top provinces in Anhui (8-yr average 0.87 billion \$), Jiangsu (0.80 billion \$) and Hubei ( 0.63 billion \$). The ECs for the north maize ranges from 1.15 billion to 3.33 billion, much higher than the south maize (Fig. 8b). Soybean has the lowest economic losses compared with the other three crops, ranging from 55 million to 291 million \$ annually (Fig. 8b), with the major contribution from Heilongjiang province (51 - 83 million \$).

\section{Discussions}

Surface ozone emerged as an important environmental issue in China, and were shown increasing trend for the past few years using both modelling and observation data, though strict clean air regulations have been implemented in China after 2013 (Lu et al., 2018, 2019; 2020; Li et al., 2020; Liu and Wang, 2020a,b; Ni et al., 2018; Wang et al., 2020). Exposure to high concentrations of surface ozone not only poses threat to human health, but also cause damages to crops. Previous studies have been using modelling results or observation data to study the crop production losses for single year (Lin et al., 2018; Feng et al., 2019; Zhao et al., 2020), or only focus on small regions, such as North China Plain (Hu et al., 2020; Feng et al., 2020). In this study, we applied chemical transport model simulation with updated annual anthropogenic emission inventory to study the long-term trend of $\mathrm{O}_{3}$-induced crop production losses from 2010 to 2017 in China. This study presented a comprehensive analysis on the impact of surface ozone exposure on four major crop production loss in China, including wheat, rice (double early and late rice, single rice), maize (north maize and south maize), and soybean. Emissions of major air pollutants, such as nitrogen dioxide and carbon monoxide, were seen to peak around 2012 or 2013 after China issued its first APPCAP. By looking at the trend from 2010 to 2017, we can capture the changes in crop production losses due to surface ozone exposure before and after the APPCAP. We adopted the AOT40 ozone metric (hourly ozone concentration over a threshold of 40 ppbv during 
https://doi.org/10.5194/acp-2021-554

Atmospheric

Preprint. Discussion started: 19 July 2021

Chemistry

(c) Author(s) 2021. CC BY 4.0 License.

and Physics

Discussions

245 the growing season) and related concentration-response function (CRF) to estimate the crop production loss (CPL) and economic loss (EL), for major crops in China, including wheat, rice, maize and soybean. We first evaluated our model's performance in simulating the growing-season AOT40 in China, and found that the CAM-Chem model was underestimating the AOT40 values, with normalized mean bias ranging from $-5 \%$ to $-28 \%$ from 2010 to 2017 , which means that the estimations for the CPL and EL in our study are conservative.

250 The annual AOT40 in China showed increasing trend since 2010, with peak in 2014, which was mainly caused by the high ozone concentration in western China. The ozone increases in mainland China were caused by a combination of unfavourable meteorological conditions, the unmitigated missions of volatile organic compounds and the decrease of $\mathrm{PM}_{2.5}$. Spatially, the annual AOT40 values were higher in western China, North China Plain, and Yangtze River Delta, with the 8-yr annual average AOT40 highest in Xizang (41.47 ppm h), Tianjin (34.79 ppm h) and Qinghai (34.51 ppm h). However, the regions with highest

255 AOT40 values do not always have higher crops planted, such as Xizang and Qinghai, making the spatial patterns of CPL and EL significantly different from the AOT40. The growing season AOT40 values are relatively higher for wheat, north maize and soybean, showing the double-hump shape for the seasonal $\mathrm{O}_{3}$ distribution (with growing season of March, April and May for wheat, and June, July and August for north maize and soybean). By using the CRF derived by Mills et al. (2007), we then calculated the relative yield loss (RYL) from the growing season AOT for each crop. We estimated that, at the province level,

260 the RYLs for wheat ranges from $8.13 \%$ to $25.14 \%, 6.72 \%$ to $10.71 \%$ for double early rice, $7.11 \%$ to $8.53 \%$ for double late rice, $6.79 \%$ to $10.22 \%$ for single rice, $0.48 \%$ to $5.29 \%$ for north maize, $0.00 \%$ to $0.94 \%$ for south maize, and $0.0 \%$ to $11.48 \%$ for soybean for the 8-yr average. The annual national average RYLs (ARYLs), which considers the fractions of the crop production loss with the hypothetical total production without ozone pollution, ranges from $11 \%$ to $22 \%$ for wheat, $8 \%$ to $9 \%$ for rice, $2 \%$ to $4 \%$ for north maize, $0 \%$ to $1 \%$ for south maize, and $1 \%$ to $3 \%$ for soybean. The estimates are comparable to

265 previous studies, such as Avnery et al (2011) reported RYLs of 3.9\%-15\% for wheat, $2.2 \%-5.5 \%$ for maize, and 8.5\%-14.0\% for soybean in 2000 for East Asia. Utilizing the regional CMAQ model, Lin et at. (2018) reported ozone induced RYLs between $8.5 \%$ and $14 \%$ for winter wheat, $9-15.0 \%$ for rice, and $2.2-5.5 \%$ for maize. Using national ozone monitoring network, Zhao et al. (2020) reported $\mathrm{O}_{3}$-induced yield reductions ranging from $20.1 \%$ to $33.3 \%$ for winter wheat, $5.0-6.3 \%$ for maize, 7.3 $8.8 \%$ for single rice, $3.9-6.8 \%$ for double-early rice and $5.9-7.1 \%$ for double-late rice.

270 Using the annual crop production from the Statistical Yearbook of China, we estimated that national aggregated CPL varies from 13.81 to 36.51 million Mt from 2010 to 2017 for wheat, which is comparable to the total wheat productions in Paris, the fifth largest wheat production in the world. The annual CPL for rice, including both double early and late rice, and single rice, is 16.89-20.03 million Mt, comparable to the annual rice productions in Philippines, the $8^{\text {th }}$ largest rice producer in the world. The CPL for maize ranges from 4.59 to 8.17 million Mt, and 0.27 - 0.34 million Mt for Soybean. Accordingly, from 2010 to 2752017 , economic losses from surface ozone exposure ranges from 3.86-14.29 billion $\$$ for wheat, 2.05 billion $\$$ to 3.87 billion $\$$ for double rice (with early and late rice contributes almost equally), 2.96 billion to 6.49 billion $\$$ for single rice, $1.16-3.53$ billion $\$$ for maize (with north maize contributing to more than $90 \%$ of the total), and $0.16-0.29$ billion $\$$ for soybean. By evaluating our model's simulation with observation results, we notice that our model simulated AOT40 ozone metrics are 
lower than the station observation data, which makes our estimations for the crop production and economic losses conservative.

Overall, from 2010 to 2017, the ozone-induced crop production loss in China is significant. The overlaps of major crop growing area, populated and industrial zones, and ozone concentration hotspots alerted the emergency of a better structured and balance control on ozone precursors to limit ozone concentration and preserve food security efficiently. The increment of ozone concentration under the scenario of stringent emission control could be attributed to the policy preference to $\mathrm{NO}_{\mathrm{X}}$ control. Management on $\mathrm{O}_{3}$ precursors in China was concentrated on $\mathrm{NO}_{\mathrm{X}}$ limitation while less control was implemented on VOCs (Wang et al., 2019). In the Beijing-Tianjin-Hebei Industrial Zone and the Shanghai-Nanjing-Hangzhou Economic Zone, however, VOCs' emission was a major influential factor that induced ozone generation. Correspondingly, the efficient control on particulate matters $\left(\mathrm{PM}_{2.5}\right.$ and $\left.\mathrm{PM}_{10}\right)$ in these regions boosted photolysis rates during the formation of ozone.

Data availability. Global anthropogenic emissions data from CEDS are available from https://www.geosci-modeldev.net/11/369/2018/ (accessed May 12 ${ }^{\text {th }}$, 2021). MEIC emission inventory is available from 290 http://meicmodel.org/?page $\mathrm{id}=560$ (last access May $6^{\text {th }}, 2021$ ). The CAM-Chem model is available at http://www.cesm.ucar.edu/models/cesm1.2/ (accessed May 12 ${ }^{\text {th }}, 2021$ ). Data from CAM-Chem modelling that support the findings of this study are available from the corresponding author upon request.

Author contributions: YZ and DS initiated the research, and designed the paper framework. YZ ran the model, and DL processed the data, performed the data analysis and made the plots. YZ and DL analysed the results and wrote the paper, with contributions from DD, XL and LZ.

Competing interests: The authors declare that they have no conflict of interest.

Acknowledgements: Y.Z. and D.S. acknowledge the support by the NASA GISS grant 80NSSC19M0138. We appreciate the efforts of the China Ministry of Ecology and Environment with respect to supporting the nationwide observation network and the publishing of hourly air pollutant concentrations. We also thank Qiang Zhang and Bo Zheng from Tsinghua

300 University for providing the MEIC emission inventory in China from 2010 to 2017. We would like to thank the University of North Carolina at Chapel Hill and the Research Computing group for providing computational resources and support that have contributed to these research results. 


\section{References}

Atkinson, R. (2000). Atmospheric chemistry of VOCs and $\mathrm{NO}_{\mathrm{x}}$. Atmospheric environment, 34(12-14), 2063-2101.

Avnery, S., Mauzerall, D. L., Liu, J. and Horowitz, L. W.: Global crop yield reductions due to surface ozone exposure: 1. Year 2000 crop production losses and economic damage, Atmos. Environ., 45(13), 2284-2296, doi:10.1016/j.atmosenv.2010.11.045, 2011..

Avnery, S., Mauzerall, D. L., Liu, J. and Horowitz, L. W.: Global crop yield reductions due to surface ozone exposure: 2.

310 Year 2030 potential crop production losses and economic damage under two scenarios of O3 pollution, Atmos. Environ., 45(13), 2297-2309, doi:10.1016/j.atmosenv.2011.01.002, 2011.

Booker, F., Muntifering, R., Mcgrath, M., Burkey, K., Decoteau, D., Fiscus, E., Manning, W., Krupa, S., Chappelka, A. and Grantz, D.: The ozone component of global change: Potential effects on agricultural and horticultural plant yield, product quality and interactions with invasive species, J. Integr. Plant Biol., 51(4), 337-351, doi:10.1111/j.1744-7909.2008.00805.x, 3152009.

Brauer, M., Freedman, G., Frostad, J., Van Donkelaar, A., Martin, R. V., Dentener, F., Dingenen, R. Van, Estep, K., Amini, H., Apte, J. S., Balakrishnan, K., Barregard, L., Broday, D., Feigin, V., Ghosh, S., Hopke, P. K., Knibbs, L. D., Kokubo, Y., Liu, Y., Ma, S., Morawska, L., Sangrador, J. L. T., Shaddick, G., Anderson, H. R., Vos, T., Forouzanfar, M. H., Burnett, R. T. and Cohen, A.: Ambient Air Pollution Exposure Estimation for the Global Burden of Disease 2013, Environ. Sci.

320 Technol., 50(1), 79-88, doi:10.1021/acs.est.5b03709, 2016.

Feng, Z. W., Jin, M. H., Zhang, F. Z., \& Huang, Y. Z. (2003). Effects of ground-level ozone $\left(\mathrm{O}_{3}\right)$ pollution on the yields of rice and winter wheat in the Yangtze River Delta. Journal of Environmental Sciences, 15(3), 360-362.

Feng, Z., Hu, E., Wang, X., Jiang, L., \& Liu, X. (2015). Ground-level $\mathrm{O}_{3}$ pollution and its impacts on food crops in China: a review. Environmental Pollution, 199, 42-48.

325 Feng, Z., De Marco, A., Anav, A., Gualtieri, M., Sicard, P., Tian, H., Fornasier, F., Tao, F., Guo, A. and Paoletti, E.: Economic losses due to ozone impacts on human health, forest productivity and crop yield across China, Environ. Int., 131(February), 104966, doi:10.1016/j.envint.2019.104966, 2019a.

Feng, Z., Kobayashi, K., Li, P., Xu, Y., Tang, H., Guo, A., Paoletti, E. and Calatayud, V.: Impacts of current ozone pollution on wheat yield in China as estimated with observed ozone, meteorology and day of flowering, Atmos. Environ., 217

330 (March), doi:10.1016/j.atmosenv.2019.116945, 2019b.

Feng, Z., Hu, T., Tai, A. P. K. and Calatayud, V.: Yield and economic losses in maize caused by ambient ozone in the North China Plain (2014-2017), Sci. Total Environ., 722, 137958, doi:10.1016/j.scitotenv.2020.137958, 2020.

Hoesly, R. M., Pitkanen, T., Vu, L., Kurokawa, J., Janssens-Maenhout, G., Andres, R. J., Kholod, N., Moura, M. C. P., Feng, L., Dawidowski, L., Seibert, J. J., Smith, S. J., Zhang, Q., Liu, L., Li, M., O\&amp;apos;Rourke, P. R., Klimont, Z., Bolt, R.

335 M., Lu, Z. and Bond, T. C.: Historical (1750-2014) anthropogenic emissions of reactive gases and aerosols from the 
Community Emission Data System (CEDS), Geosci. Model Dev., 11(1), 369-408, doi:https://doi.org/10.5194/gmd-11-3692018, 2018.

Hollaway, M. J., Arnold, S. R., Challinor, A. J., and Emberson, L. D.: Intercontinental trans-boundary contributions to ozoneinduced crop yield losses in the Northern Hemisphere, Biogeosciences, 9, 271-292, https://doi.org/10.5194/bg-9-271-2012, 2012.

Hu, T., Liu, S., Xu, Y., Feng, Z. and Calatayud, V.: Assessment of $\mathrm{O}_{3}$-induced yield and economic losses for wheat in the North China Plain from 2014 to 2017, China, Environ. Pollut., 258, 113828, doi:10.1016/j.envpol.2019.113828, 2020.

Krupa, S. V., Nosal, M., \& Legge, A. H. (1998). A numerical analysis of the combined open-top chamber data from the USA and Europe on ambient ozone and negative crop responses. Environmental Pollution, 101(1), 157-160.

345 Li, K., Jacob, D. J., Zhang, Q., Liao, H., Bates, K. H. and Shen, L.: Anthropogenic drivers of 2013-2017 trends in summer surface ozone in China, Proc. Natl. Acad. Sci., 116(2), 422-427, doi:10.1073/pnas.1812168116, 2019.

Li, K., Jacob, D. J., Liao, H., Zhu, J., Shah, V., Shen, L., ... \& Zhai, S. (2019). A two-pollutant strategy for improving ozone and particulate air quality in China. Nature Geoscience, 12(11), 906-910.

Li, K., Jacob, D. J., Shen, L., Lu, X., De Smedt, I., and Liao, H.: Increases in surface ozone pollution in China from 2013 to 350 2019: anthropogenic and meteorological influences, Atmos. Chem. Phys., 20, 11423-11433, https://doi.org/10.5194/acp-2011423-2020, 2020.

Li, M., Liu, H., Geng, G., Hong, C., Liu, F., Song, Y., Tong, D., Zheng, B., Cui, H., Man, H., Zhang, Q. and He, K.: Anthropogenic emission inventories in China: A review, Natl. Sci. Rev., 4(6), 834-866, doi:10.1093/nsr/nwx150, 2017. Lin, Y., Jiang, F., Zhao, J., Zhu, G., He, X., Ma, X., Li, S., Sabel, C. E. and Wang, H.: Impacts of $\mathrm{O}_{3}$ on premature mortality 355 and crop yield loss across China, Atmos. Environ., 194(July), 41-47, doi:10.1016/j.atmosenv.2018.09.024, 2018. Liu, Y. and Wang, T. (2020a). Worsening urban ozone pollution in China from 2013 to 2017 - Part 1: The complex and varying roles of meteorology. Atmospheric Chemistry and Physics, 20(11), 6305-6321. https://doi.org/10.5194/acp-20-63052020.

Liu, Y. and Wang, T. (2020b). Worsening urban ozone pollution in China from 2013 to 2017 - Part 2: The effects of emission changes and implications for multi-pollutant control. Atmospheric Chemistry and Physics, 20(11), 6323-6337. https://doi.org/10.5194/acp-20-6323-2020.

Lu, X., Hong, J., Zhang, L., Cooper, O. R., Schultz, M. G., Xu, X., Wang, T., Gao, M., Zhao, Y. and Zhang, Y.: Severe Surface Ozone Pollution in China: A Global Perspective, Environ. Sci. Technol. Lett., 5(8), 487-494, doi:10.1021/acs.estlett.8b00366, 2018.

365 Lu, X., Zhang, L., Chen, Y., Zhou, M., Zheng, B., Li, K., Liu, Y., Lin, J., Fu, T.-M., and Zhang, Q.: Exploring 2016-2017 surface ozone pollution over China: source contributions and meteorological influences, Atmos. Chem. Phys., 19, 8339-8361, https://doi.org/10.5194/acp-19-8339-2019, 2019.

Lu, X., Zhang, L., Wang, X., Gao, M., Li, K., Zhang, Y., Yue, X. and Zhang, Y.: Rapid Increases in Warm-Season Surface Ozone and Resulting Health Impact in China Since 2013, Environ. Sci. Technol. Lett., doi:10.1021/acs.estlett.0c00171, 2020. 
Mills, G., Buse, A., Gimeno, B., Bermejo, V., Holland, M., Emberson, L. and Pleijel, H.: A synthesis of AOT40-based response functions and critical levels of ozone for agricultural and horticultural crops, Atmos. Environ., 41(12), 2630-2643, doi:10.1016/j.atmosenv.2006.11.016, 2007.

National Bureau of Statistics of China. (2018). National data. http://data.stats.gov.cn

Ni, R., Lin, J., Yan, Y., and Lin, W.: Foreign and domestic contributions to springtime ozone over China, Atmos. Chem. Phys., 18, 11447-11469, https://doi.org/10.5194/acp-18-11447-2018, 2018.

Ohara, T. A. H. K., Akimoto, H., Kurokawa, J. I., Horii, N., Yamaji, K., Yan, X., \& Hayasaka, T. (2007). An Asian emission inventory of anthropogenic emission sources for the period 1980-2020. Atmospheric Chemistry and Physics, 7(16), 44194444.

Piikki, K., De Temmerman, L., Ojanperä, K., Danielsson, H., \& Pleijel, H. (2008). The grain quality of spring wheat (Triticum

380 Aestivum L.) in relation to elevated ozone uptake and carbon dioxide exposure. European Journal of Agronomy, 28(3), 245254.

Rosenzweig, C., Elliott, J., Deryng, D., Ruane, A. C., Müller, C., Arneth, A., ... \& Neumann, K. (2014). Assessing agricultural risks of climate change in the 21st century in a global gridded crop model intercomparison. Proceedings of the National Academy of Sciences, 111(9), 3268-3273.

385 Singh, A. A., Agrawal, S. B., Shahi, J. P., \& Agrawal, M. (2014). Assessment of growth and yield losses in two Zea mays L. ultivars (quality protein maize and nonquality protein maize) under projected levels of ozone. Environmental Science and Pollution Research, 21(4), 2628-2641.

Tang, H., Takigawa, M., Liu, G., Zhu, J., \& Kobayashi, K. (2013). A projection of ozone-induced wheat production loss in China and India for the years 2000 and 2020 with exposure-based and flux-based approaches. Global Change Biology, 19(9),

$390 \quad 2739-2752$.

The Royal Society, 2008. Ground-level ozone in the 21st century: future trends, impacts 1980-2020. Atmos. Chem. Phys. 7 (16), 4419-4444. Olivier, J.G.J., Berdowski, J.J.M., 2001. Global emissions sources and sinks. In: and policy implications. Sci. Policy Rep. 15/08, 1-148.

USDA, 2016. http://www.usda.gov/oce/weather/pubs/Other/MWCACP/index.htm.

395 Van Dingenen, R., Dentener, F. J., Raes, F., Krol, M. C., Emberson, L. and Cofala, J.: The global impact of ozone on agricultural crop yields under current and future air quality legislation, Atmos. Environ., 43(3), 604-618, doi:10.1016/j.atmosenv.2008.10.033, 2009..

Van Dingenen, R., Dentener, F., Crippa, M., Leitao, J., Marmer, E., Rao, S., Solazzo, E. and Valentini, L.: TM5-FASST: A global atmospheric source-receptor model for rapid impact analysis of emission changes on air quality and short-lived climate pollutants, Atmos. Chem. Phys., 18(21), 16173-16211, doi:10.5194/acp-18-16173-2018, 2018.

Wang, N., Lyu, X., Deng, X., Huang, X., Jiang, F., \& Ding, A. (2019). Aggravating $\mathrm{O}_{3}$ pollution due to $\mathrm{NO}_{\mathrm{x}}$ emission control in eastern China. Science of The Total Environment, 677, 732-744. 
https://doi.org/10.5194/acp-2021-554

Atmospheric

Preprint. Discussion started: 19 July 2021

Chemistry

(c) Author(s) 2021. CC BY 4.0 License.

and Physics

Discussions

Wang, X., \& Mauzerall, D. L. (2004). Characterizing distributions of surface ozone and its impact on grain production in China, Japan and South Korea: 1990 and 2020. Atmospheric Environment, 38(26), 4383-4402.

Wang, X., Zhang, Q., Zheng, F., Zheng, Q., Yao, F., Chen, Z., ... \& Feng, Z. (2012). Effects of elevated $\mathrm{O}_{3}$ concentration on winter wheat and rice yields in the Yangtze River Delta, China. Environmental Pollution, 171, 118-125.

Wang, Y., Zhang, Y., Hao, J., and Luo, M.: Seasonal and spatial variability of surface ozone over China: contributions from background and domestic pollution, Atmos. Chem. Phys., 11, 3511-3525, https://doi.org/10.5194/acp-11-3511-2011, 2011.

Wang, Y., Gao, W., Wang, S., Song, T., Gong, Z., Ji, D., Wang, L., Liu, Z., Tang, G., Huo, Y., Tian, S., Li, J., Li, M., Yang, Y., Chu, B., Petäjä, T., Kerminen, V. M., He, H., Hao, J., Kulmala, M., Wang, Y. and Zhang, Y.: Contrasting trends of PM $_{2.5}$ and surface-ozone concentrations in China from 2013 to 2017, Natl. Sci. Rev., 7(8), 1331-1339, doi:10.1093/nsr/nwaa032, 2020.

Zhang, L., Jacob, D. J., Boersma, K. F., Jaffe, D. A., Olson, J. R., Bowman, K. W., Worden, J. R., Thompson, A. M., Avery, M. A., Cohen, R. C., Dibb, J. E., Flock, F. M., Fuelberg, H. E., Huey, L. G., McMillan, W. W., Singh, H. B., and Weinheimer,

415 A. J.: Transpacific transport of ozone pollution and the effect of recent Asian emission increases on air quality in North America: an integrated analysis using satellite, aircraft, ozonesonde, and surface observations, Atmos. Chem. Phys., 8, 61176136, https://doi.org/10.5194/acp-8-6117-2008, 2008.

Zhang, L., Jacob, D. J., Knipping, E. M., Kumar, N., Munger, J. W., Carouge, C. C., van Donkelaar, A., Wang, Y. X., and Chen, D.: Nitrogen deposition to the United States: distribution, sources, and processes, Atmos. Chem. Phys., 12, 4539-4554, https://doi.org/10.5194/acp-12-4539-2012, 2012.

Zhang, L., Shao, J., Lu, X., Zhao, Y., Hu, Y., Henze, D. K., ... \& Zhang, Q. (2016). Sources and processes affecting fine particulate matter pollution over North China: an adjoint analysis of the Beijing APEC period. Environmental science \& technology, 50(16), 8731-8740.

Zhang, Q., Zheng, Y., Tong, D., Shao, M., Wang, S., Zhang, Y., Xu, X., Wang, J., He, H., Liu, W., Ding, Y., Lei, Y., Li, J., Wang, Z., Zhang, X., Wang, Y., Cheng, J., Liu, Y., Shi, Q., Yan, L., Geng, G., Hong, C., Li, M., Liu, F., Zheng, B., Cao, J., Ding, A., Gao, J., Fu, Q., Huo, J., Liu, B., Liu, Z., Yang, F., He, K. and Hao, J.: Drivers of improved $\mathrm{PM}_{2.5}$ air quality in China from 2013 to 2017, Proc. Natl. Acad. Sci. U. S. A., 116(49), 24463-24469, doi:10.1073/pnas.1907956116, 2019. Zhang, W., Feng, Z., Wang, X., Liu, X., \& Hu, E. (2017). Quantification of ozone exposure-and stomatal uptake-yield response relationships for soybean in Northeast China. Science of The Total Environment, 599, 710-720.

Zhang, Y., Cooper, O. R., Gaudel, A., Thompson, A. M., Nédélec, P., Ogino, S. Y. and West, J. J.: Tropospheric ozone change from 1980 to 2010 dominated by equatorward redistribution of emissions, Nat. Geosci., 9(12), 875-879, doi:10.1038/ngeo2827, 2016.

Zhang, Y., J. J. West, F. J., Emmons, L., Sudo, K., Takemura, T., Flemming, J., Jonson, J. E., Lund, M. T., Gaudel, A., Chang, K-L., Nedelec, P. and Thouret, V. (2020) Regional emission changes contributions to the global tropospheric ozone burden change from 1980 to 2010 (accepted by GRL). 
https://doi.org/10.5194/acp-2021-554

Preprint. Discussion started: 19 July 2021

(c) Author(s) 2021. CC BY 4.0 License.

(c) (1)

Zheng, B., Tong, D., Li, M., Liu, F., Hong, C., Geng, G., Li, H., Li, X., Peng, L., Qi, J., Yan, L., Zhang, Y., Zhao, H., Zheng, Y., He, K. and Zhang, Q.: Trends in China's anthropogenic emissions since 2010 as the consequence of clean air actions, Atmos. Chem. Phys., 18(19), 14095-14111, doi:10.5194/acp-18-14095-2018, 2018.

Zhao, C., Liu, B., Piao, S., Wang, X., Lobell, D. B., Huang, Y., Huang, M., Yao, Y., Bassu, S., Ciais, P., Durand, J. L., 440 Elliott, J., Ewert, F., Janssens, I. A., Li, T., Lin, E., Liu, Q., Martre, P., Müller, C., Peng, S., Peñuelas, J., Ruane, A. C., Wallach, D., Wang, T., Wu, D., Liu, Z., Zhu, Y., Zhu, Z. and Asseng, S.: Temperature increase reduces global yields of major crops in four independent estimates, Proc. Natl. Acad. Sci. U. S. A., 114(35), 9326-9331, doi:10.1073/pnas.1701762114, 2017.

Zhao, H., Zheng, Y., Zhang, Y. and Li, T.: Evaluating the effects of surface $\mathrm{O}_{3}$ on three main food crops across China during 445 2015-2018, Environ. Pollut., 258, 113794, doi:10.1016/j.envpol.2019.113794, 2020. 
Table 1: The concentration-response function for the relative yields (RY) for ozone exposure on different crops.

\begin{tabular}{|c|c|c|}
\hline Crops & concentration response function & Growing season \\
\hline Wheat & $\mathrm{RY}=-0.0016 \times \mathrm{AOT} 40+0.99$ & MAR, APR, MAY \\
\hline Rice & $\mathrm{RY}=-0.0039 \times \mathrm{AOT} 40+0.94$ & $\begin{array}{l}\text { MAY, JUN, JUL (Double Early Rice }{ }^{1} \text { ) } \\
\text { SEP, OCT, NOV (Double Late Rice²) } \\
\text { AUG, SEP, OCT (Single Rice) }\end{array}$ \\
\hline Maize & $\mathrm{RY}=-0.0036 \times \mathrm{AOT} 40+1.02$ & $\begin{array}{l}\text { JUN, JUL, AUG (North Maize }{ }^{3} \text { ) } \\
\text { AUG, SEP, OCT (South Maize }{ }^{4} \text { ) }\end{array}$ \\
\hline Soybean & $\mathrm{RY}=-0.0116 \times \mathrm{AOT} 40+1.120$ & JUN, JUL, AUG \\
\hline
\end{tabular}

${ }^{1}$ Double early/late rice is considered to grow in Zhejiang, Jiangxi, Anhui, Hunan, Hubei, Fujian, Guangdong, Guangxi, Hainan, Yunnan, Hongkong, Macao and Taiwan (Lin et al., 2019; Zhao et al., 2019).

${ }^{2}$ Single rice is considered to grow in Heilongjiang, Jilin, Liaoning, Hebei, Beijing, Tianjin, Shanxi, Shaanxi, Ningxia, Gansu, 450 Xinjiang, Nei Mongol, Shanghai, Jiangsu, Zhejiang, Anhui, Fujian, Jiangxi, Shandong, Henan, Hubei, Hunan, Guangxi, Sichuan, Chongqing, Guizhou and Yunnan (Lin et al., 2019; Zhao et al., 2019).

${ }^{3}$ North maize is considered to grow in northern provinces, including Heilongjiang, Jilin, Liaoning, Beijing, Tianjin, Hebei, Henan, Shandong, Shanxi, Shaanxi, Gansu, Qinghai, Ningxia, Nei Mongol, Xinjiang and Anhui (NBSC, 2018; Zhou et al., 2019).

$455{ }^{4}$ South maize are in southern provinces only, including Shanghai, Jiangsu, Zhejiang, Fujian, Jiangxi, Hubei, Hunan, Guangdong, Guangxi, Sichuan, Chongqing, Guizhou, Xizang, Yunnan, Hainan, Hongkong, Macao and Taiwan (NBSC, 2018; Zhou et al., 2019). 


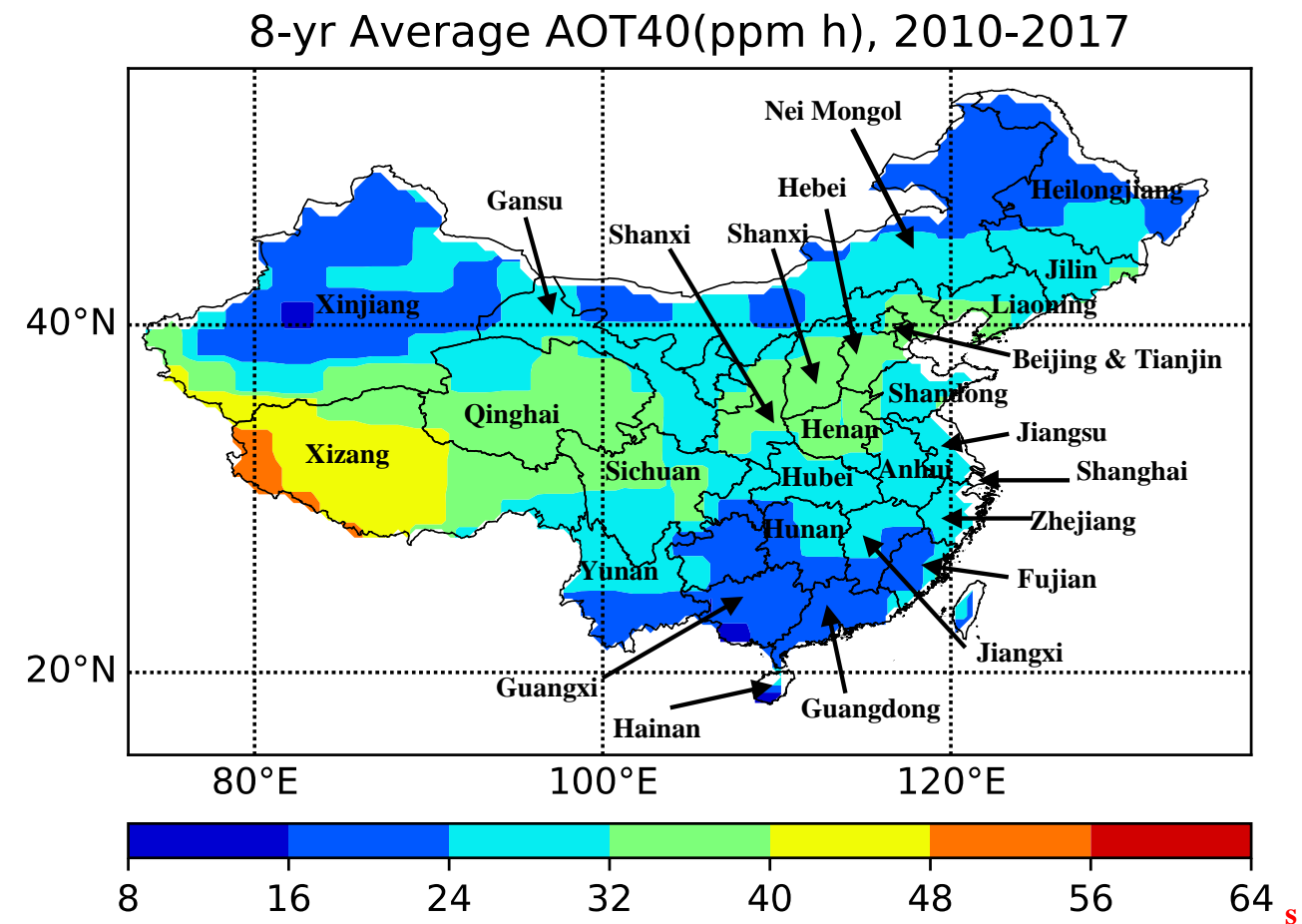

Figure 1: Spatial distribution of annual accumulated AOT40 (ppm h) in China for 8-year average (from 2010 to 2017$).$

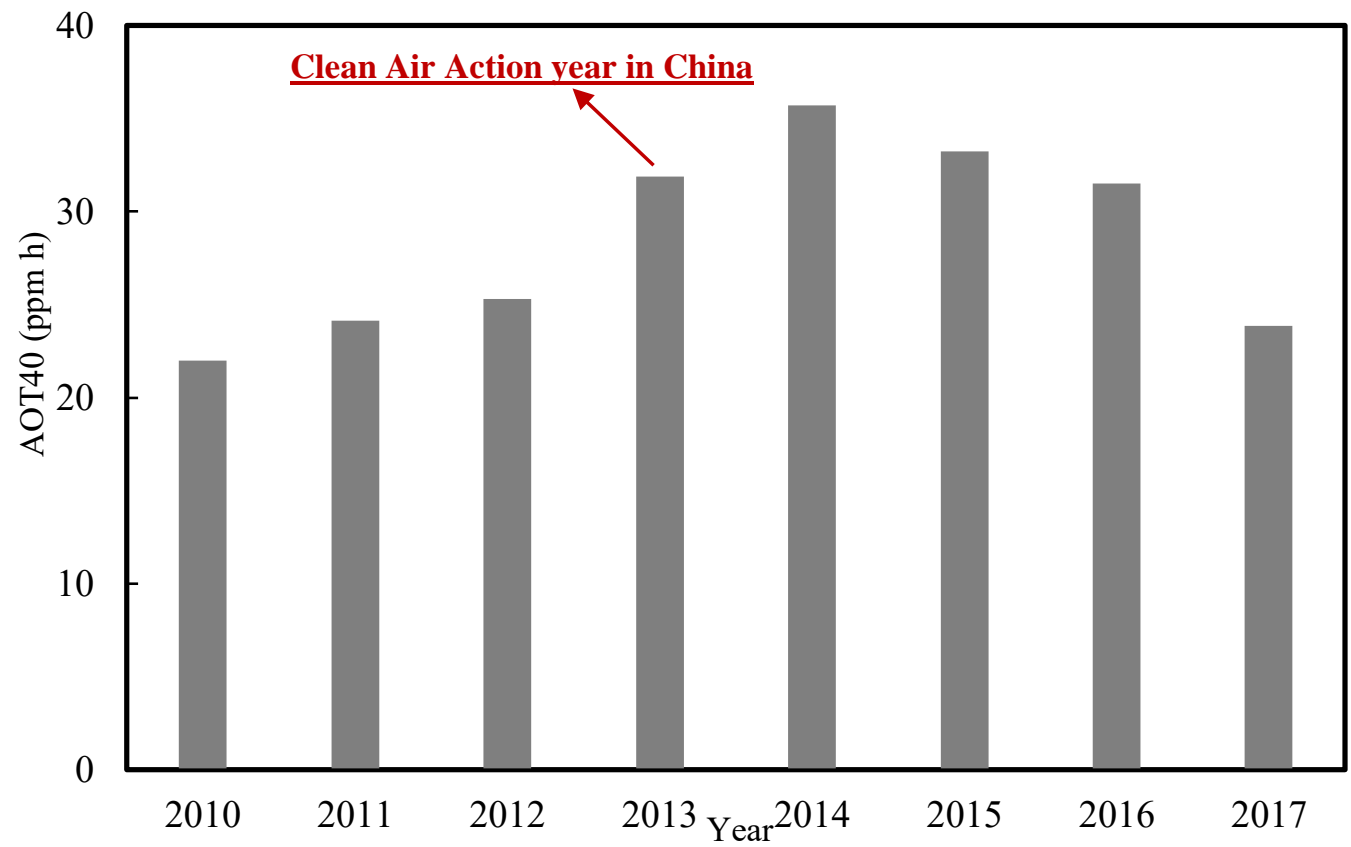

Figure 2: The national annual accumulated AOT40 values in China from 2010 to 2017. The unit is ppm $\mathrm{h}$. 
https://doi.org/10.5194/acp-2021-554

Preprint. Discussion started: 19 July 2021

(c) Author(s) 2021. CC BY 4.0 License.

(c) (i)
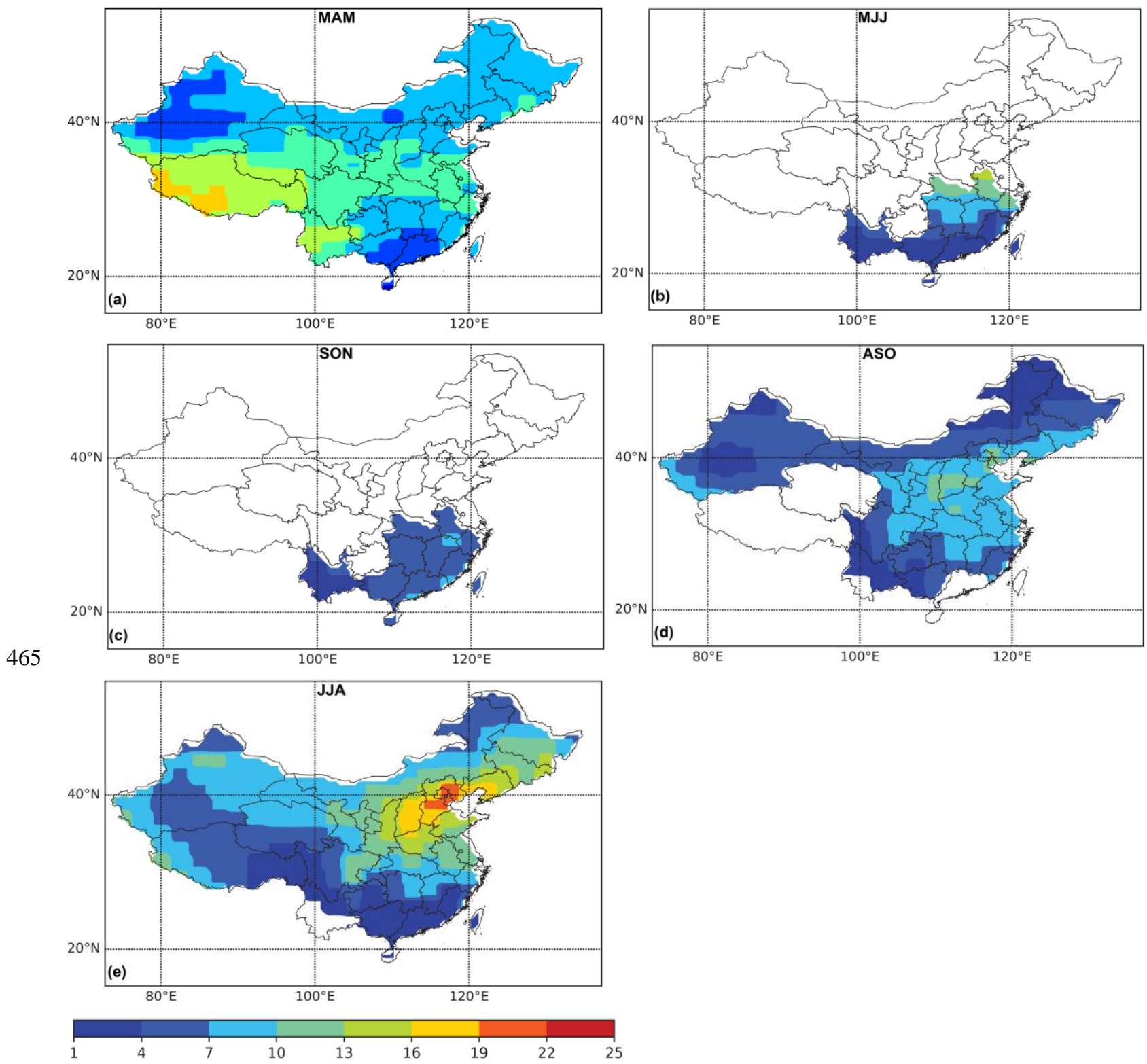

Figure 3: The spatial distribution of 8-yr average growing season accumulated AOT40 for (a) wheat, (b) double early rice, (c) double late rice, (d) single rice and south maize, and (e) soybean and north maize. The unit is ppm $h$.
Chemistry

and Physics

Discussions
Atmospheric 


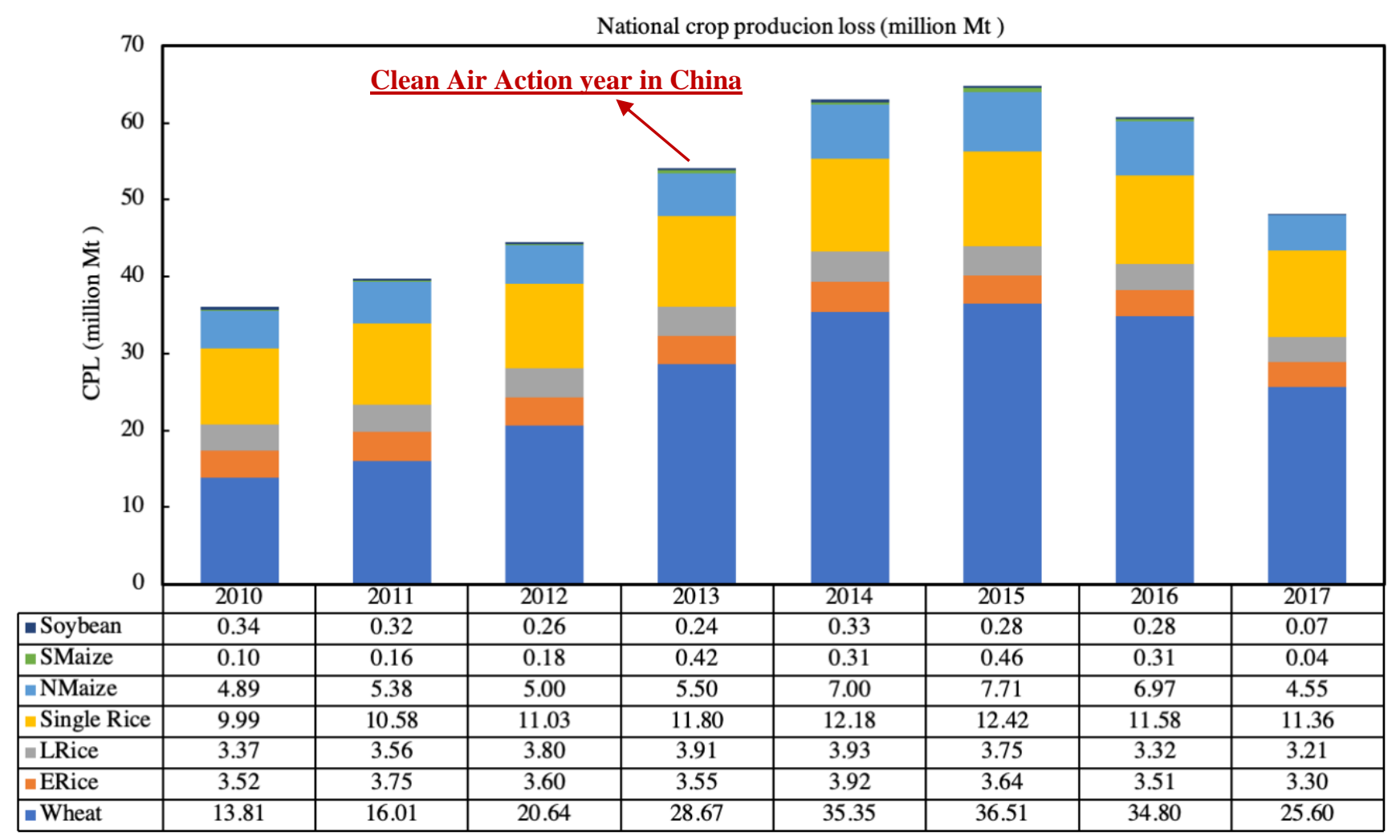

Figure 4: National crop production loss for major crops, with SMaize for south maize, NMaize for north maize, LRice for Late Rice, ERice for early rice. Unit is million metric tons. 
https://doi.org/10.5194/acp-2021-554

Preprint. Discussion started: 19 July 2021

(c) Author(s) 2021. CC BY 4.0 License.
Atmospheric

Chemistry

and Physics

Discussions
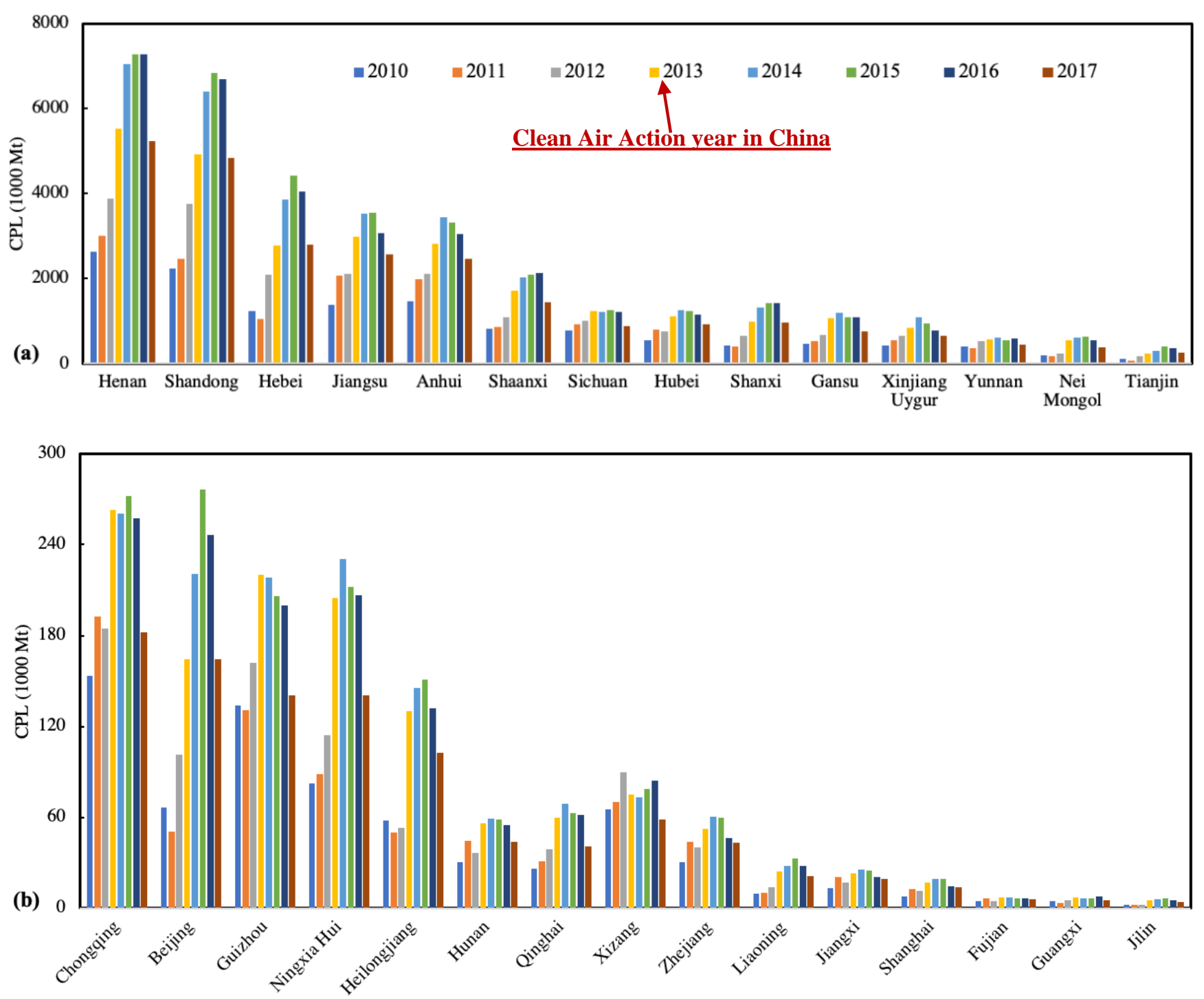

Figure 5: Annual wheat production loss by province from 2010 to 2017 (1000 Mt) due to surface ozone exposure. 

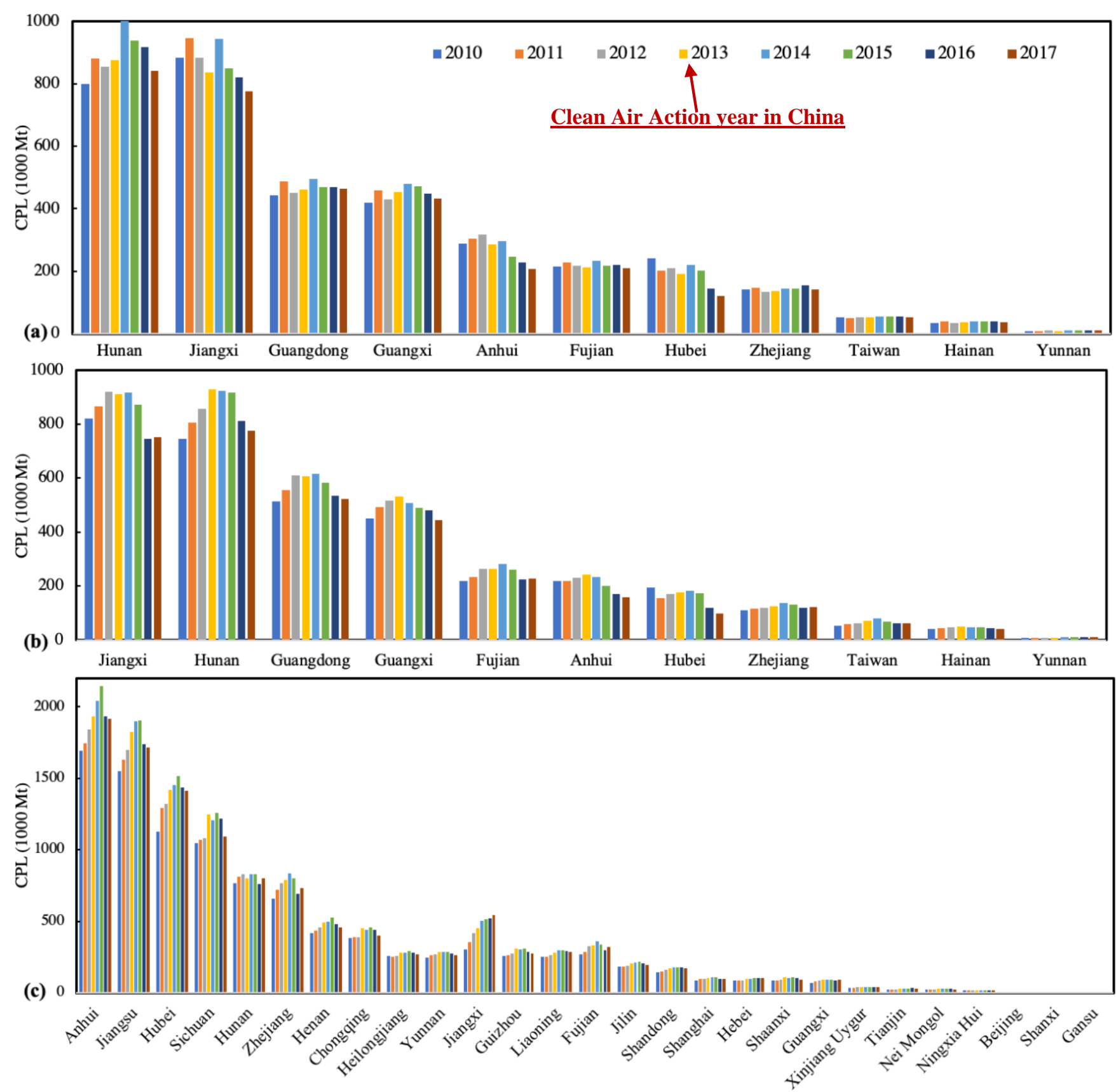

Figure 6: The production losses for rice, including double early rice (a), double late rice (b), and single rice (c) in all the China provinces. Units of thousands Mt. 
https://doi.org/10.5194/acp-2021-554

Preprint. Discussion started: 19 July 2021

(C) Author(s) 2021. CC BY 4.0 License.

\section{Atmospheric \\ Chemistry \\ and Physics \\ Discussions}

\section{National ARYLs}

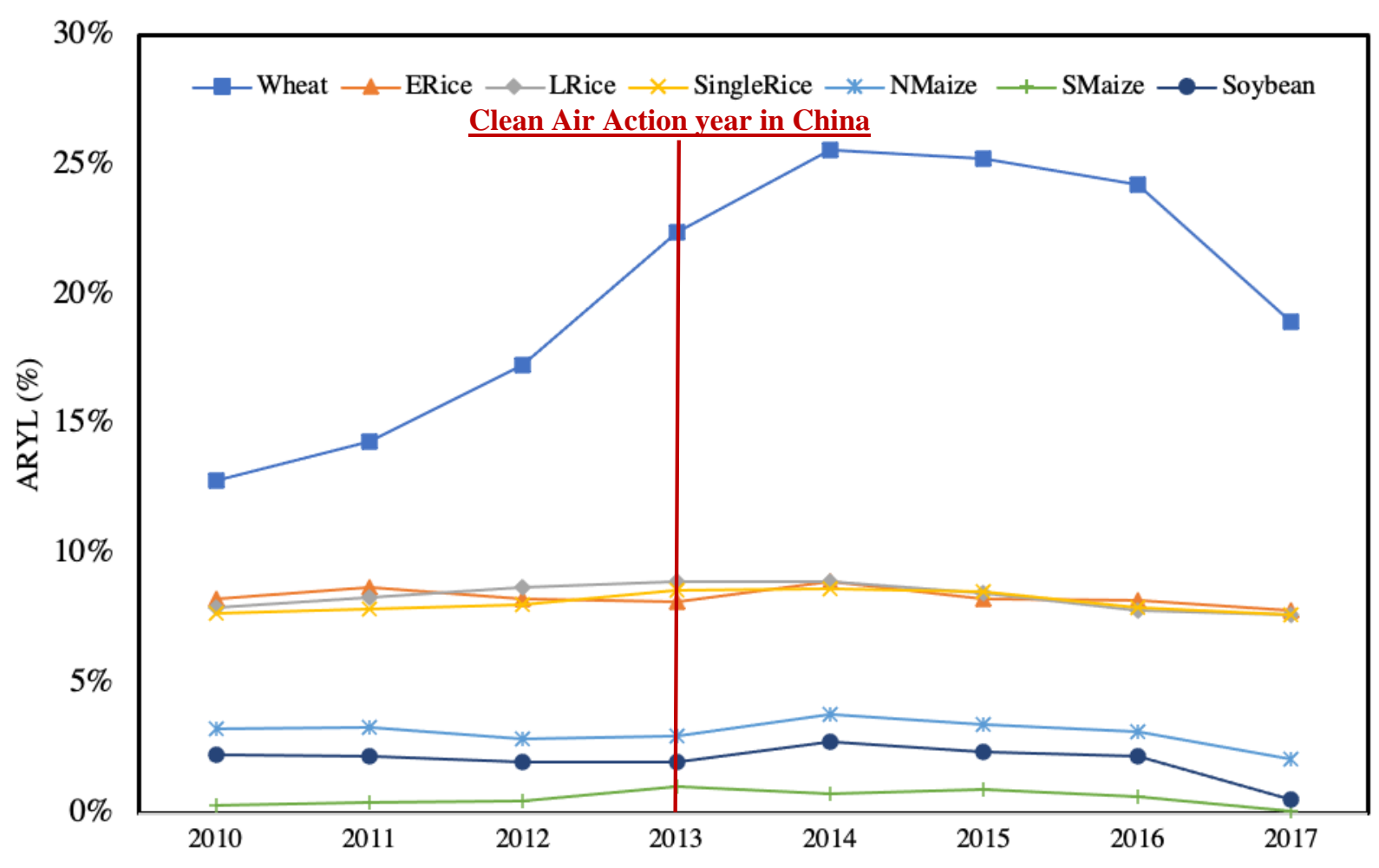

Figure 7: National average relative yield loss (ARYLs) from 2010 to 2018. The south maize (SMaize) and soybean are multiplied by 485 10 to be comparable with other crops. 

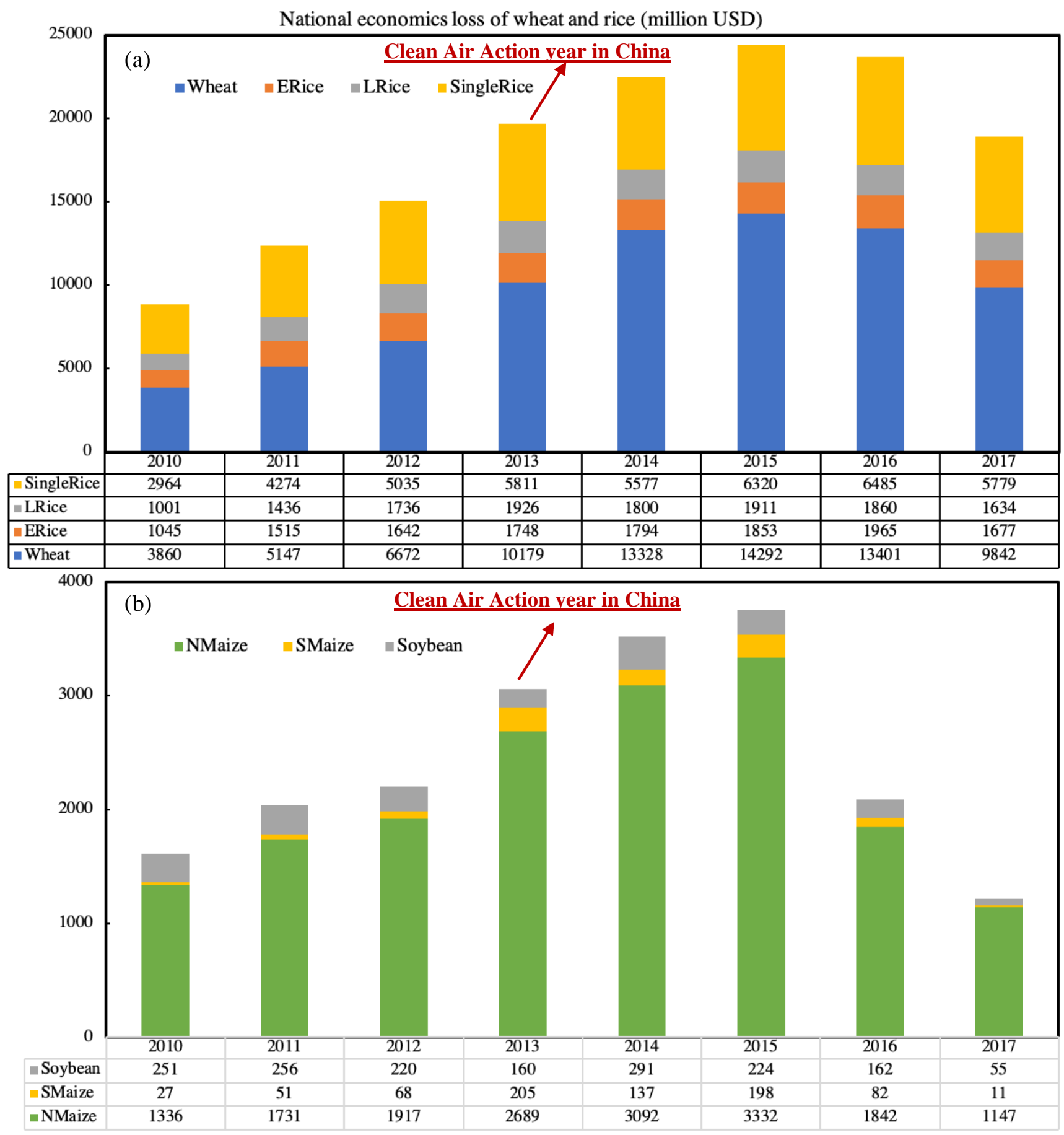

Figure 8: National economic loss from cop production loss from wheat and rice (double early \& late rice, single rice) (a), and maize (north maize and south maize), and soybean (b) from 2010 to 2017. The units are million USD. 